Брайченко Тетяна Федосіївна,

кандидат педагогічних наук, доцент

доцент кафедри академічного

i естрадного вокалу та звукорежисури

Національної академії керівних кадрів

культури і мистецтв

ORCID 0000-0002-7359-2946

tefebra@gmail.com

\title{
ПОЕТИКА АКАДЕМІЧНИХ І ЕСТРАДНИХ ПІСЕНЬ У СУЧАСНИХ УКРАЇНСЬКИХ АВТОРІВ
}

\begin{abstract}
Мета статті - здійснити екскурс у творчість сучасних авторів та виявити особливості музично-поетичних рішень в академічних і естрадних піснях. Методологія роботи грунтується на використанні методів порівняльного аналізу; узагальнення - для концептуалізації музично-поетичних втілень в академічних творах і естрадних піснях сучасників. Наукова новизна роботи полягає у виявленні особливостей музично-поетичних рішень в академічних $\mathrm{i}$ естрадних піснях сучасних авторів. Висновки. На основі аналізу пісень сучасних авторів визначено, що сучасна творчість насичена різноманітними проявами поетичних рішень. Домінуючі поетичні рішення у пісенному жанрі пов'язані із передачею ліричних почугтів та політичних, громадсько-побугових хронікальних подій (пісні-хроніки). Поетична складова цих пісень транслює інформацію сьогодення та історії. Це віддзеркалюється у творчості українських поетів і композиторів академічного (Л. Дичко, І. Карабиць, А. Комлікова, В. Степурко) та естрадного напрямів (Т. Кароль, Р. Лижичко). У поетиці пісень академічного і естрадного спрямувань використано поєднання народного i сучасного елементів і в поезії, і в музичному рішенні, що стає характерною рисою для сучасної української творчості.
\end{abstract}

Ключові слова: поетика, сучасна творчість, академічний спів, естрадна пісня, авторська пісня.

Брайченко Татьяна Федосеевна, кандидат педагогических наук, дочент, дочент кафедры академического и эстрадного вокала и звукорежсссуры Национальной академии руководящих кадров культуры и искусств

Поэтика академических и эстрадных песен у современных украинских авторов

Цель статьи - совершить экскурс в творчество современных авторов и выявить особенности музыкальнопоэтических решений в академических и эстрадных песнях. Методология работы основывается на использовании методов сравнительного анализа; обобщения - для концептуализации музыкально-поэтических воплощений в академических произведениях и эстрадных песнях современников. Научная новизна работы заключается в выявлении особенностей музыкально-поэтических решений в академических и эстрадных песнях современных авторов. Выводы. На основе анализа песен современных авторов определено, что современное творчество насыщено разнообразными проявлениями поэтических решений. Поэтические решения в песенном жанре связанные с передачей лирических чувств и политических, общественно-бытовых хроникальных событий (песни - хроники). Поэтическая составляющая этих песен транслирует информацию дня сегодняшнего и исторического прошлого. Это отражается в творчестве украинских поэтов и композиторов академического (Л. Дычко, И. Карабиц, А. Комликова, В. Степурко) и эстрадного направлений (Т. Кароль, Р. Льжичко). В поэтике песен академического и эстрадного направлений использовано сочетание народного и современного элементов и в поэзии, и в музыкальном решении, что становится характерной чертой для современного украинского творчества.

Ключевые слова: поэтика, современное творчество, академическое пение, эстрадная песня, авторская песня.

Braichenko Tetiana, Ph.D., Associate Professor of the Department of Academic and Pop Vocals and Sound Engineering of the National Academy of Managerial Staff of Culture and Arts.

Poetics of academic and pop songs by contemporary Ukrainian authors

The purpose of the article is to make an excursion into the work of modern authors and to reveal the features of musical and poetic decisions in academic and pop songs. The methodology of work is based on the use of comparative analysis methods; generalizations - for the conceptualization of musical and poetic incarnations in academic works and pop songs of contemporaries. The scientific novelty of the work is to identify the features of musical and lyrical decisions in the academic and pop songs of modern authors. Conclusions. Thus, the study of song poetics confirms the relevance and prospect of the study, as academic and variety singing in contemporary music is gaining in popularity previously unprecedented. In the modern space of culture, there are more and more competitions, programs, festivals of academics, and pop singing. The research interest in Ukrainian academic and variety songs in its intonational origins and components, its embeddedness in the world context, reveals a modern interpretation of stylistic national and innational ways. Based on the analysis of songs by contemporary authors, it is determined that contemporary creativity is saturated with various manifestations of poetic decisions. Poetic decisions in the song genre associated with the transfer of lyrical feelings and political, social, and everyday chronical events (songs - chronicles). The poetic component of these songs broadcasts information on the day of the present and historical past. This is reflected in the work of Ukrainian poets and composers of the academic (L. Dychko, I. Karabits, A. Komlikova, V. Stepurko) and pop (T. Karol,

(СБрайченко Т. Ф., 2019 
R. Lyzhichko). In the poetics of songs of the academic and pop trends, a combination of folk and modern elements was used both in poetry and in the musical decision, which becomes a characteristic feature for contemporary Ukrainian creativity.

Key words: poetics, contemporary art, academic singing, pop song, original song.

Актуальність теми дослідження. Термін «поетика» $є$ складним філософським поняттям, яке зустрічається у творчості Аристотеля, який вперше в історії обгрунтував античні знання про світ і розподілив літературу на епос, лірику і драму. Якщо звернутися до пісні, то саме лірика складає іiі основу. Вивчення поетики пісень підтверджує актуальність і перспективність дослідження, оскільки академічний і естрадний спів у сучасній музиці набуває своєї небаченої раніше популярності. У сучасному просторі культури виникає все більше конкурсів, програм, фестивалів академічного і естрадного співу. Дослідницький інтерес до української академічної та естрадної пісні в іiі інтонаційних витоках і складових, iї вмонтованості у світовий контекст виявляе сучасну інтерпретацію стилістичних національних та інонаціональних способів.

Аналіз досліджень і публікацій. В останні два десятиліття проблема академічної та естрадної пісні у соціокультурному просторі культури розглядається у музикознавстві, однак поетика пісень ще не отримала свого узагальнення. Можна виокремити групи досліджень у ракурсі музичної естради та естрадної пісні (О. Зосім, О. Мозгова, Т. Самая, О. Шевченко). Роботи присвячені джазовому, поп-рок мистецтву доповнюють і розширюють спектр естрадного виконавства (В. Овсянніков, Т. Рябуха, І. Палкіна).

У дисертації І. Палкіної основну увагу приділено жанроутворенню у рок-мистецтві на міжвидовій та внутрішньовидовій взаємодії. Авторка простежує генезис рок-мистецтва із поступовим накопиченням рис академічного музичного мистецтва та фольклору. Дисертантка розкриває синтетичність та ансамблевість рок-мистецтва. Результатом взаємопроникнення стали мелодекламаційний жанр, рокопера, рок-ораторія. Саме такий підхід розширює спектр як академічного, так і інших видів вокалу.

Дисертаційне дослідження В. Овсяннікова присвячене українському поп-року у контексті розвитку популярної музичної культури XX - початку XXI століття. Автор аналізує значну кількість композицій, виконавців, колективів, які від академічного вокалу прийшли до альтернативних напрямів сучасного мистецтва.

У науковій роботі В. Тормахової розглянуто особливості інтерпретації в джазі (Київ, 2017). Грунтовним вітчизняним дослідженням тематики сучасного мистецтва, стала дисертаційна робота Д. Теребуна, у якій висвітлено особливості джазу як діалогічного мистецтва (2019). Автор звертає увагу на походження джазу, його музичні витоки, вивчення діалогічного потенціалу джазу та його сутності i закономірності існування як «складної художньо-естетичної системи» [4, с. 1].

Метою статті $\epsilon$ здійснення культурологічного екскурсу у творчість сучасних авторів та виявлення особливостей музично-поетичних рішень в академічних і естрадних піснях.

Виклад основного матеріалу. Вивчаючи пісню або інші вокальні жанри, неможливо не звернути увагу на естрадні пісні, що характеризуються передачею неординарних подій політичної, громадськопобутової та родинно-побутової тематики. Їх прийнято називати піснями-хроніками. Поетична складова цих пісень транслює інформацію сьогодення так і історичного минулого.

Пісні-хроніки зустрічаються у творчості більшості композиторів академічного та естрадного спрямування. Оскільки інформація про події сучасності - це животрепетна передача почуттів і переживань. Наприклад, поетика пісень чоловічого тріо «Льомі Льом» 3 м. Одеса, яке було створене О. Ломинським на початку 1990-х років (назва групи утворилася від псевдоніма ії лідера, який працював діджеєм). Або пісня-хроніка гурту «Гринджоли» 3 м. Івана-Франківська 3 виконанням гімну «помаранчевої революції». Ця пісня була побудована на реальних подіях 2004 року із подробицями, тобто хронікою часу. Поетика таких пісень близька до історичних пісень та балад. В їх основу, як правило, покладено історичні факти перебігу однієї події.

На конкурсі «Евробачення» (2004 р.) прозвучала пісня-хроніка Руслани «Wild Dancez» із групою Cool before, що віддзеркалила фольклорні традиції у сучасній творчості.

Дикі танці та дика вода як презентація творчості сучасників. Пісня Т. Кароль «Дика вода» також віддзеркалює сучасну творчість, але ії природа полягає в естрадній мелодиці. Хоча можна знайти й фольклорну природу. Мелодія пісні із багаторазовим повторенням характерна як для сучасної творчості, так і для народної. Можемо згадати того ж «Щедрика». Одна поспівка звучить багаторазово, забарвлюючись багатоголоссям, у професійних майстрів - гармонічним супроводом (приміром, «Щедрик» В. Мужчиля). Гармонічний супровід більш розвинений, але теж примітивний. У кліпі кульмінація досягається завдяки візуальному ряду, одягу співачки. Дощ візуально цементує дійство. Дощ на вулиці, дощ у душі, дощ підкорює природу й людину. Зміст поетичного тексту передано візуально, а 
музично - дуже опосередковано. Хоча для слухачів і поціновувачів творів Т. Кароль - ця пісня $\epsilon$ шедевром.

Пісні-хроніки можна віднести й до ліричної поетики, оскільки вони інформують про авторські чи взагалі людські почуття. У поетиці пісень Тіни Кароль домінує ліричність почуттів: «Безкінечність», «Чоловіки моєї мрії», «Намалюю тобі зорі», «Обіцяй» та ін. Композиція «Show me your love» Тiни Кароль, яку співачка виконала на конкурсі «Свробачення, 2006», містить елементи українського фольклору. Після цього співачка випустила дебютний диск, який отримав статус «золотого», із однойменною назвою «Show me your love» із англомовними піснями. Звичайно, співачка звертається й до рідної мови, але від того лірична поетика не змінюється, приміром, у піснях «Перечекати» чи «Здатися ти завжди встигнеш». Музичне оформлення пісень досить просте.

Якщо про поетику естрадних пісень можна писати багато, то академічна творчість та поетика в ній $\epsilon$ досить проблемною i недостатньо дослідженою темою. Академічний спів має штучність звуковидобування і характерний для відтворення оперних партій, романсів та номерів 3 оперет або мюзиклів. Тому слід розглядати твори українських композиторів, які пишуть опери, романси, мюзикли тощо. Такі приклади $\epsilon$, але їх виконання більш проблематичне, оскільки сьогодні постановка опери сучасного композитора - явище досить виняткове.

У сучасній музикознавчий літературі є низка досліджень присвячених академічному вокалу, де обгрунтовуються специфіка звукоутворення, історичні етапи його становлення. Доречно згадати оперу для дітей сучасного українського композитора, лауреата Національної премії України імені Тараса Шевченка Віктора Степурка «Музична крамничка». В.Степурко написав чимало музики до театральних вистав. Серед них музика до лялькової вистави «Пан Коцький» (1981), аранжування для симфонічного оркестру дитячої опери Миколи Лисенка «Коза-дереза» (1984). Для дорослих була написана опера «Зальотний» за однойменним оповіданням В. Шукшина (1983), у якій розкривається доля художниканевдахи. Персонаж «Зальотний» не досягнув мети, приїхав на схилі років із міста в село. Поетика твору Шукшина доволі проста - доля звичайної людини теж $є$ певною піснею-хронікою, що розкриває особливості свого часу. Опера була написана для камерного складу оркестру й трьох співаків-солістів. I до сих пір чекає своїх виконавців.

Дитяча опера В. Степурка «Музична крамничка» (1987) була написана за мотивами однойменної казки Л. Легут. Лібрето та вірші опанував В. Довжик. Поетика опери стосується казкових персонажів, а тому мелодії, які використав композитор пісенні. Гармонії різноманітні та вишукані, що відповідають музичній мові XX століття та нагадують музичні твори для дітей С. Прокоф’єва, Д. Кабалевського, Ю. Щуровського. Ритми, які вживає композитор, часто джазові, притаманні цьому періоду розвитку музичного мистецтва. Не дивлячись на те, що опера написана для дітей, присутня виконавська традиція академічного співу $з$ кантиленністю, наспівністю. Звуки мелодій відтворюють без декламації. Хоча окремі номери наближені до інтонацій мовлення (партія Мухи).

Виконавська техніка пов'язана із інтерпретацією. Колись Б. Асаф’єв виділив основні інтонаційномовні форми, які Є. Назайкінський застосував до співу як до інтерпретації: 1) мелодекламація; 2) скандування; 3) співуче читання; 4) псалмодія; 5) жартівлива скоромовка; 6) оперний речитатив; 7) аріозний спів; 8) кантиленна арія; 9) протяжна народна пісня; 10) побутовий романс; 11) циганський спів; 12) камерно-вокальна лірика концертного плану [2, с. 135].

Український дослідник В. Яромчук аналізує перспективи використання академічного вокалу в XXI ст. А практику цього виконання і різновиди, що застосовує до співу Б. Асаф'єв та Є. Назайкінський, можна розглянути на прикладі творчості молодої української композиторки, випускниці Київської консерваторії Анастасії Комликової. І хоча їі наукова робота була присвячена специфіці жанру рок-опери в контексті розвитку української культури, вона у своій творчості звертається до жанрів академічної та естрадної музики. В неї є опера «Самотність», яка у чомусь перегукується із твором В. Губаренка «Листи кохання». В академічному вокалі головний акцент робиться на вокальних даних самого співака. При цьому важливою умовою є розвиток вокальної партії. Тому опера А.Комликової «Самотність» презентує яскраво виражені мелодії, що відтворюються професійно підготовленими співаками.

Відомі два цикли естрадних пісень Анастасії Комликової «Птахи і квіти» (2004) та «Емоції» (2006 2008). Поетика циклу пісень «Емоції» досить різноманітна. Інструментально-вокальний вступ до пісні «Замок» поєднує дві традиції - колористику сучасності та фольклорне забарвлення, що далі продовжується в піснях «Ой рано, рано», «Правда», «В темнім морі», «Великий шлях». У кожній пісні ці поєднання відрізняються одне від одного, але протиставлення є всюди.

Мелодії пісні «Дівчина в вінку» відсилає пам'ять до гуцульського фольклору. А програші $є$ просто мелодіями, наповненими фольклорними інтонаціями і ритмами. У пісні «Коханому» яскраво виражений ритм вірша, при чому в дуже простій римтоформулі. Пісня «Мама» $є$ своєрідною присвятою 
найдорожчий людині в світі. Мелодія пісні протяжна, але ії природа естрадна, а не народна. Розвиток пісні простий, побудова куплетна. Виконання пісні поєднує народну і естрадну манери. Пісня циклу «Метро» передає емоції, що виникають у людини при зустрічі із невідомим і відомим, знайомим $\mathrm{i}$ незнайомим. Романсова лірика притаманна пісні «Я піду туди...» (на слова Л. Забашти).

Отже, у циклі А. Комлікової ««Емоції» можемо спостерігати поєднання поетики стилів академічного та естрадного вокалу із народними, фольклорними традиціями.

Визначити особливості чи просто відокремити академічну музику / пісню від неакадемічної досить проблематично. У творчості українського композитора Івана Карабиця багато пісень (понад 50), що виконують естрадні та академічні співаки. Вокальний цикл І. Карабиця «Мати» на вірші Б. Олійника (1980) пронизаний українським народним мелосом. Мелодія «Мати наша - сивая горлиця» інтонаційно взагалі нагадує народну пісню, а згодом стає основою для творів інших композиторів. Поетика пісень цього циклу близька до передачі композитором своєї громадянської позиції. Така тематика характерна для іншого циклу композитора «На березі вічності» для голосу з фортепіано (1977).

Академічний спів відтворюється у циклах пісень I. Карабиця «Пастелі» на слова П. Тичини для сопрано і фортепіано (1970) та «Ранкова сюїта» для голосу та естрадно-симфонічного оркестру на вірші В. Батюка і В. Губарця (1978-1980). Поетика пісень циклу «Пастелі» зосереджена на символічному світі, який композитор передає сучасними засобами: вільно побудованими мелодіями із широкими стрибками та ін. Віршований цикл «Пастелі» геніального українського поета Павла Тичини складається із чотирьох філософськи наснаженних символічних мініатюр «Ранок», «День», «Вечір», «Ніч». Партія фортепіано досить колористична, але із мінімалізмом вираження. Лірико-пленерний тип поетики музичними засобами малює картини природи.

Філософські роздуми про вічні категорії буття віддзеркалені у циклах І. Карабиця «Із пісень Хіросіми» для голосу і флейти на вірші Йосаку Йонеди (1973) та «П’ять пісень» на вірші Р. Тагора (1995). Тексти східних поетів мають експресіоністичне забарвлення та передають різні образи через символіку. Цикл «П'ять пісень» складається із любовних романсів «Кохання - одвічна ріка», «На березі ставка», «Подих», «Нескінченне», «Сумнів». Для музичної мови характерні політональність, полігармонійність, східна поліритмічність у поєднанні із західною ритмічністю.

У доробку І. Карабиця відомі й джазові імпровізації. А сьогодні виконавці самі роблять аранжування, активізуючи джазові ритми пісень І. Карабиця. До пісень І. Карабиця «Де вітер трави колише» i «Вийду, вийду зранку в поле» учасник проекту «Танок на майдані Конго» Діля додав джазовий вокаліз.

На презентації монографії Любові Кияновської «Сад пісень Івана Карабиця» прозвучав романс композитора на слова Максима Рильського «Яблука доспіли, яблука червоні» також у джазовій обробці.

Тож, у творчості Івана Карабиця зустрічаємо пісні різних напрямів. Поетика його пісень вражає різноманітністю. Образи пісень від фольклорних, ліричних до сучасних джазових рішень. Як пише українська дослідниця Лілія Назар-Шевчук «Спочатку було Слово..., і діалог між Словом і Звуком ведеться споконвіку. Та й звук без слів - у невербальній іпостасі - наділений грандіозним смисловосемантичним енергетичним полем, потрясаючим асоціативним рядом, який так часто “бере нас за душу”, працюючи на глибинах підсвідомого чи й позасвідомого, на безмежних просторах космосу людських сердець» [3, с. 189].

Відомий видавець «Дух і Літера» Леонід Фінберг пише, що «“несказане лишилось несказанним..."», а музика I. Карабиця продовження є певним «діалогом у пошуках співдії раціо та емоціо, прагми і пневми, гармонію рівноваги між якими так довго шукає людство, розкриваючи ще одну паралель - Дух і Нота. І такі книги як «Дочекатися музики» та «Діалоги» Валентина Сильвестрова, «Сад пісень Івана Карабиця» Любові Кияновської - невеликі, та для когось вкрай необхідні сходинки на шляху, вказаному Сковородою: "Пізнай самого себе”» [3, с. 190].

Неможливо сплутати спів у академічній манері зі співом у естрадній чи народній. Навіть для кожної країни $є$ свої виконавці, впізнавані всіма громадянами. В Україні такою співачкою $є$ Ніна Матвієнко. Саме цій співачці присвячені збірники пісень Ганни Гаврилець «Золотий камінь посіємо...» $\mathrm{i}$ опера Лесі Дичко «Золотослов».

У музично-сценічному дійстві Ганни Гаврилець «Золотий камінь посіємо...» використані пісні, які були віднайдені Ніною Матвієнко у різних регіонах України. Це низка музичних дійств, які можна порівняти із історичними українськими фресками. Шість частин складають цілісне дійство. Але для цієї публікації цікава пісня-романс ««Засвічу свічу» для голосу та камерного оркестру. Вона написана в куплетній формі. Починається пісня інструментальним вступом. Мелодія пісні доспівується інструментальними побудовами. При чому різними тембрами: флейтою, струнними. 
Хорова опера «Золотослов» (1992р.) Л. Дичко є новаторською за своєю сутністю. Ї̈̈ експеримент спрямований на поєднання первісного народного синкретизму 3 авторською мовою без цитат i адаптувань. Одна із частин «Плач» 3 цієї опери була написана спеціально для Ніни Матвієнко. Протяжну мелодію композиторка у симфонічному перекладі доручила скрипці. Л. Кияновська зазначає, що «Саме пісенність - не як конкретний жанр, а як узагальнена естетична категорія, $з$ їі стійкими метафорами, символами, конкретними персонажами і сюжетними поворотами міцно увійшла як елемент професійного художнього мислення в українське мистецтво» [1, с. 25].

Опера Л. Дичко була написана після появи збірки фольклорних текстів «Золотослов. Поетичний космос Давньої Русі» (видавництво «Дніпро»,1988). Збірка складалася з фольклорних пісень. Особливого значення для композиторки набули календарно-обрядові пісні (весняного і зимового календарного циклу), родинно-побудові пісні, весільні пісні, плачі. Образи пісень та народні традиції були покладені в основу опери «Золотослов». Етимологія слова містить два звернення «золото» і «сонячне світло». Два символи, що уособлюють образи давньоукраїнської міфології. Композиторка синтезує поетичні тексти, звертаючись саме до міфологічного значення. Поєднання академічного й народного співу характерне для соліста.

У сучасній творчості українських композиторів відчутний вплив західноєвропейського вокального мистецтва, зокрема, поєднання академічного та естрадного вокалу. Наприклад, у проектах Фредді Мерк’юрі (лідер гурту «Queen») та видатної оперної співачки Монтсеррат Кабальє - «Barcelona» (1988) прозвучали пісні: «Barcelona», «La Japonaise», «The Fallen Priest», «Ensueño», «The Golden Boy», «Guide Me Home», «How Can I Go On», «Overture Piccante».

Слухаючи оперу Л. Дичко «Золотослов», згадується те, що значне поширення академічного вокалу відбувалося в середині XX ст. завдяки кіно- та телемистецтву. Дослідник Л. Данько проаналізував фільми, в яких вокальні номери активно сприяли драматургічному розвитку сюжетів. Видатні співаки середини XX ст. популяризували академічний спів. Серед них варто відзначити американського тенорового оперного співака і актора Маріо Ланца.

Висновки. На основі аналізу пісень сучасних авторів слід зазначити, що сучасна творчість насичена різноманітними проявами поетичних рішень. Домінуючі поетичні рішення у пісенному жанрі пов'язані із передачею ліричних почуттів та політичних, громадсько-побутових хронікальних подій (пісні-хроніки). Поетична складова цих пісень транслює інформацію про події сьогодення та знаменні сторінки минулого. Це віддзеркалюється у творчості українських поетів і композиторів академічного (Л. Дичко, І. Карабиць, А. Комлікова, В. Степурко) та естрадного напрямів (Т. Кароль, Р. Лижичко). У поетиці пісень академічного і естрадного спрямувань поєднуються як народні, так і сучасні елементів і в поезії, і в музичному рішенні, що стає характерною рисою для сучасної української творчості.

\section{Jimepamypa}

1. Кияновська Л. М. Скорик. Стильова еволючия Галищької музичної культури XIX-XX cm. Тернопіль : Астон, 2000. С. 294-319.

2. Назайкинский Е. В. Стиль и жанр в музыке : учеб. пособие. Москва : Владос, 2003. 248 с.

3. Назар-Шевчук Лілія. Запрошення до «Саду пісень Івана Карабиця» : рецензія на монографію Л. Кияновської «Сад пісень Івана Карабиця». Вісник Національної академії керівних кадрів культури і мистецттв. Київ : Міленіум, 2017. №3. С. $189-190$.

4. Теребун Д. С. Джаз як мистецтво діалогу: автореферат дис... кандидата мистецтвознавства за спеціальністю 26.00 .01 «Теорія та історія культури». Національна академія керівних кадрів культури $\mathrm{i}$ мистецтв. Київ, 2019. 23 с.

\section{References}

1. Kiyanovska L. (2000). Skoryk. Style evolution of Galician musical culture of the XIX-XX centuries. Ternopil: Aston. [in Ukrainian].

2. Nazaykinsky E. (2003). Style and genre in music: textbook. allowance. Moscow: Vlados. 248 p. [in Russia].

3. Nazar-Shevchuk Lily. (2017). Invitation to Ivan Karabits' Garden of Songs: review of L. Kiyanowska's monograph "Garden of Ivan Karabits Songs". Bulletin of the National Academy of Art and Culture Leadership. Kyiv: Millennium. [in Ukrainian].

4. Terebun D. (2019). Jazz as the art of dialogue: author's abstract Candidate of Arts degree in specialty 26.00.01 "Theory and History of Culture". National Academy of Culture and Arts. Kyiv. 23 p. [in Ukrainian]. 